\title{
Analisis Pertumbuhan Penjualan Dan Perputaran Modal Kerja Terhadap Profitabilitas PT. Tiga Pilar Sejahtera Food, Tbk Tahun 2012-2016.
}

\author{
Supanji Setyawan, Susilowati \\ Universitas Tidar \\ supanji@untidar.ac.id; sushi_waty@yahoo.com
}

\begin{abstract}
This study aims to analyze whether there is influence of variable sales growth and working capital turnover on corporate profitability. Sample in this study is the PT. Tiga Pilar Sejahtera Food, Tbk. Data used in this research is secondary data that of annual report of PT. Tiga Pilar Sejahtera Food, tbk in 2012-2015. Data collection method used is documentation. The result of research with multiple linear regression analysis method showed that the partial sales growth variable had a significant positive effect on profitability while the working capital turnover had no significant effect on profitability. The author recommends that companies pay more attention to, utilize and process resources owned to improve corporate profits, so that the increase in corporate profitability can be achieved.
\end{abstract}

Keyword: growth sales, working capital turnover, profitability

\begin{abstract}
Abstrak
Penelitian ini bertujuan untuk menganalisis ada tidaknya pengaruh dari variabel pertumbuhan penjualan dan perputaran modal kerja terhadap profitabilitas (ROA) perusahaan. Sampel dalam penelitian ini adalah PT. Tiga Pilar Sejahtera Food, Tbk. Data yang digunakan dalam penelitian ini adalah data sekunder yaitu data laporan keuangan PT. Tiga Pilar Sejahtera Food, Tbk tahun 2012-2015. Metode pengumpulan data yang digunakan adalah dokumentasi. Hasil penelitian dengan metode analisis regresi linear berganda menunjukkan variabel pertumbuhan penjualan secara parsial berpengaruh positif signifikan terhadap profitabilitas sedangkan perputaran modal kerja berpengaruh negatif tidak signifikan terhadap profitabilitas. Penulis merekomendasikan agar perusahaan lebih memperhatikan, memanfaatkan serta menngolah sumber daya yang efektif untuk meningkatkan laba perusahaan sehingga peningkatan profitabilitas perusahaan dapat dicapai.
\end{abstract}

Kata kunci: Pertumbuhan Penjualan, Perputaran Modal Kerja, Profitabilitas

Diterima: 11 Februari 2108; Revisi: 2018; Disetujui: 2018 


\section{PENDAHULUAN}

Secara umum, tujuan suatu perusahaan didirikan adalah untuk menghasilkan laba bagi pemiliknya (Rudianto, 2006). Laba yang dihasilkan perusahaan erat hubungannya dengan tingkat profitabilitas perusahaan itu sendiri. Rasio profitabilitas menggambarkan kemampuan perusahaan mendapatkan laba melalui semua kemampuan dan sumber yang ada seperti kegiatan penjualan, kas, modal, jumlah karyawan, jumlah cabang, dan sebagainya (Harahap, 2011:304). Profitabilitas yang tinggi menunjukkan semakin efektif perusahaan dalam menjalankan operasinya sehingga mampu meningkatkan laba yang optimal.

Sebaliknya, profitabilitas yang rendah menggambarkan bahwa perusahaan kurang efisien dalam menjalankan operasinya sehingga kurang mampu menghasilkan laba yang optimal. PT. Tiga Pilar Sejahtera Food, Tbk merupakan perusahaan manufaktur. Dalam pencapaian tujuan perusahaan yaitu menghasilkan laba, maka setiap produk yang dihasilkan tersebut dijual kepada pelanggan. Penjualan menjadi kegiatan utama untuk memperoleh pendapatan sehingga laba perusahaan dapat dioptimalkan. Penjualan tersebut dapat berlangsung dengan adanya modal kerja yang membiayainya. Sehingga, penjualan dan modal kerja menjadi faktor untuk menghasilkan laba perusahaan. Berikut adalah data penjualan dan modal kerja serta laba bersih PT. Tiga Pilar Sejahtera Food, Tbk tahun 2012-2015:

Tabel 1. Data Penjualan, Modal kerja, dan Laba Bersih PT. Tiga Pilar Sejahtera Food, Tbk tahun 2012-2015 (Dalam ribuan rupiah)

\begin{tabular}{|c|r|r|r|}
\hline Tahun & \multicolumn{1}{|c|}{ Penjualan } & \multicolumn{1}{c|}{ Modal Keria } & \multicolumn{1}{c|}{ LabaBersih } \\
\hline 2012 & 2.747 .623 & 1.544 .940 & 253.664 \\
\hline 2013 & 4.056 .735 & 2.445 .504 & 346.728 \\
\hline 2014 & 5.139 .974 & 3.977 .086 & 378.142 \\
\hline 2015 & 6.010 .895 & 4.463 .635 & 373.750 \\
\hline Jumlah & 17.955 .227 & 12.431 .165 & 1.352 .284 \\
\hline
\end{tabular}

Dari tabel 1, dapat diketahui bahwa penjualan PT. Tiga Pilar Sejahtera Food, Tbk tahun 2012-2015 mengalami peningkatan. Hal tersebut berarti PT. Tiga Pilar Sejahtera Food, Tbk tahun 2012-2015 memiliki kinerja yang baik dilihat dari 
segi penjualan. Sedangkan modal kerja mengalami peningkatan setiap tahunnya dari tahun 2012-2015. Namun, jika dilihat dari besarnya laba yang diperoleh PT. Tiga Pilar Sejahtera Food, Tbk tahun 20122015, perusahaan ini mempunyai laba yang fluktuatif yaitu terjadi peningkatan pada tahun 2012-2014 sedangkan pada tahun 2015 mengalami penurunan. Peningkatan pada penjualan dan modal kerja yang tidak disertai pada peningkatan laba bersih menimbulkan dugaan bahwa modal kerja tidak digunakan secara efektif.

Keadaan tersebut dikhawatirkan dapat mempengaruhi tingkat profitabilitas perusahaan. Oleh karena itu, dengan adanya peningkatan penjualan dan modal kerja ini apakah dapat memicu perubahan pada profitabilitas perusahaan, yang mana perubahan tersebut menentukan kinerja perusahaan yang dicapai pada periode bersangkutan.

Penelitian Tujuan penelitian ini untuk mendiskripsikan adanya pengaruh pertumbuhan penjualan terhadap Return On Assets (ROA) PT. Tiga Pilar Sejahtera Food, Tbk tahun 2012-2015. Serta untuk mendiskripsikan adanya pengaruh perputaran modal kerja terhadap Return On Assets (ROA) PT. Tiga Pilar Sejahtera Food, Tbk tahun 2012-2015. Manfaat dari penelitian ini diharapkan dapat menjadi bahan masukan dan sumbangan pemikiran yang dapat menambah pengetahuan khususnya mengenai profitabilitas perusahaan.

\section{METODE}

Penelitian ini bersifat kuantitatif dengan populasi perusahaan manufaktur yang terdaftar di BEI sektor industri barang konsumsi pada sub industri makanan dan minuman tahun 2015 sebanyak 14 perusahaan sesuai dengan publikasi Indonesian Stock Exchange. Sampel dalam penelitian ini adalah perusahaan PT. Tiga Pilar Sejahtera Foods, Tbk. Teknik analisis analisis yang digunakan adalah analisis linear berganda.

Variabel penelitian yang digunakan dalam penelitian ini yaitu; (1) Pertumbuhan penjualan; (2) Perputaran Modal Kerja; dan (3) Return On Assets (ROA). 
Pertumbuhan penjualan merupakan rasio yang dapat digunakan untuk menggambarkan kenaikan penjualan perusahaan tahun ini dibandingkan dengan penjualan tahun lalu. Proksi yang digunakan dalam penelitian ini adalah growth yaitu selisih antara jumlah penjualan periode ini dengan periode sebelumnya dibandingkan dengan penjualan periode sebelumnya, sebagaimana penelitian yang dilakukan oleh Meidiyustiani (2016) dengan rumus:

$$
\text { Growth }=\frac{\text { penjualan tahun ini-penjualan tahun lalu }}{\text { penjualan tahun lalu }}
$$

Perputaran modal kerja merupakan salah satu rasio yang digunakan untuk mengukur atau menilai keefektifan modal kerja perusahaan selama periode tertentu.Dalam penelitian ini modal kerja diproksikan oleh working capital turnover sesuai dengan penelitian Meidiyustiani (2016). Dengan rumus sebagai berikut :

$$
\text { WCT }=\frac{\text { Penjualan Bersih }}{\text { Aktiva Lancar - Utang Lancar }}
$$

Rasio ini menggambarkan perputaran aktiva diukur dari volume penjualan. Dalam penelitian ini, digunakan Return On Assets (ROA) sebagai proksi dari profitabilitas karena return on assets memberikan penjelasan perihal kemampuan perusahaan dalam memperoleh laba dengan menggunakan asset yang dimilki, sebagaimana dalam penelitian yang dilakukan Meidiyustiani (2016). Dengan rumus sebagai berikut :

$$
\mathrm{ROA}=\frac{\text { Laba Bersih }}{\text { Total Aset }}
$$

Penelitian ini menggunakan jenis data sekunder, yaitu data yang diperoleh peneliti dari sumber yang sudah ada, dalam penelitian ini data yang dipakai adalah laporan keuangan tahunan PT. Tiga pilar Sejahtera Foods,Tbk yang diperoleh dari situs resmi yaitu Annual Report PT.Tiga Pilar Sejahtera Food,Tbk tahun 2015. Metode yang digunakan untuk mengumpulkan data dalam penelitian ini adalah metode dokumentasi, yaitu dengan cara mengumpulkan data laporan keuangan tahunan PT. Tiga Pilar Sejahtera Foods, Tbk dari tahun 2012 sampai dengan 2015. 
Hasil Berikut adalah data pertumbuhan penjualan, dan rasio reutn on assets PT. Tiga Pilar Sejahtera Foods, Tbk dari tahun 2012 sampai dengan tahun 2015:

Data rasio growth, working capital turnover, dan ROA PT. Tiga Pilar Sejahtera Foods, Tbk tahun 2012-2015:

Tabel 1. Data rasio growth, working capital turnover, dan ROA

\begin{tabular}{llll}
\hline Tahun & Growth & $\begin{array}{l}\text { Working } \\
\text { Turnover (WTC) }\end{array}$ & $\begin{array}{c}\text { Capital } \\
\text { Return On Asset (ROA) }\end{array}$ \\
\hline 2012 & 0.2 & 3.5 & 0.04 \\
2013 & 0.3 & 2.1 & 0.05 \\
2014 & 0.5 & 3.9 & 0.06 \\
2015 & 0.6 & 8.4 & 0.06
\end{tabular}

Berdasarkan data pada tabel 1, dapat diketahui prosentase pertumbuhan penjualan PT. Tiga pilar Sejahetra foods, Tbk kurang mampu mengoptimalkan penjualan dari tahun ke tahun karena rasio pertumbuhan penjualan yang semakin menurun sehingga, mempengaruhi tingkat laba bersih yang dihasilkan.Dari rasio working capital di atas yang mengalami fluktuasi menunjukkan bahwa PT.Tiga Pilar Sejahtera Foods, Tbk pada tahun 2015 kurang efektif penggunaannya pada periode tersebut. Rasio profitabilitas (ROA) PT. Tiga Pilar Sejahtera Foods,Tbk menunjukkan rasio yang kurang baik. Penggunaan aktiva belum efisien untuk meningkatkan volume penjualannya. Sehingga laba usaha belum optimal.

Uji validitas dan reliabilitas dalam penelitian ini digunakan untuk mengetahui data yang digunakan adalah data valid dan reliabel. Berikut hasil uji validitas dan reliabilitas yang diolah.

Tabel 2. Hasil Uji Validitas

\begin{tabular}{lll}
\hline VARIABEL & & RASIO \\
\hline \multirow{2}{*}{ RASIO GROWTH } & Pearson Correlation & 0,953 \\
& sig. & 0,047 \\
\hline \multirow{2}{*}{ RASIO WCT } & Pearson & $-0,928$ \\
& Correlation & 0,072 \\
\hline
\end{tabular}


Berdasarkan tabel uji validitas, dihasilkan rhitung lebih besar dari rtabel dengan $\mathrm{N}=2$ pada taraf signifikan 0.05 sebesar $0.953>0.950$ dengan tingkat signifikan $0.047<0.05$. Hal ini menunjukkan bahwa item pertumbuhan penjualan valid dan dapat digunakan (diterima) dalam penelitian. Sedangkan item perputaran modal kerja memiliki nilai rhitung sebesar $-0.928<0.950$ dengan tingkat signifikan $0.072>0.05$. Hal tersebut berarti bahwa perputaran modal kerja tidak berkorelasi secara signifikan terhadap ROA.

Tabel 3. Hasil Uji Reliabilitas

\begin{tabular}{ll}
\hline Variabel & $\begin{array}{l}\text { Corrected } \\
\text { Item- Total }\end{array}$ \\
\hline \multirow{2}{*}{ Rasio Growth } & Corelation \\
Rasio ROA & .953 \\
\hline
\end{tabular}

Tabel 3 menunjukkan hasil uji reliabilitas pada pertumbuhan penjualan dengan nilai rhitung sebesar $0.953>0.950$ maka item penelitian yang mengukur variabel ROA tersebut dinyatakan reliabel, sehingga dapat digunakan dalam pengujian hipotesis.

Pengujian Data Dalam penelitian ini, hipotesis diuji dengan menggunakan analisis berganda (multiple regression analysis). Sebelum melakukan pengujian terhadap hipotesis, data dilakuakan pengujian terhadap asumsi-asumsi regresi linear atau uji asumsi klasik terlebih dahulu yang bertujuan untuk menghindari kesalahan spesifikasi model regresi yang digunakan serta untuk menghindari munculnya bias dalam analisis data.

Uji statistic $\mathrm{t}$ atau uji parsial dilakukan untuk mengetahui signifikansi pengaruh seberapa jauh variabel independen secara parsial atau sendiri-sendiri dalam menerangkan variabel dependen. Dari hasil pengolahan data diperoleh hasi output sebagai berikut :

Tabel 4. Hasil Uji t

\begin{tabular}{lll}
\hline \multirow{2}{*}{ Model } & \multicolumn{2}{l}{ Colinearity statistic } \\
\cline { 2 - 3 } & Tolerance & VIF \\
\hline Rasio Growth & 0,397 & 2.517
\end{tabular}


Rasio WTC $\quad 0,397 \quad 2.517$

Berdasarkan tabel tersebut, maka dapat dibuat suatu persamaan sebagai berikut:

$\mathrm{Y}=\mathrm{a}+\mathrm{b} 1 \mathrm{X} 1+\mathrm{b} 2 \mathrm{X} 2 \mathrm{Y}=0.032+0,069 \mathrm{X} 1-0.002 \mathrm{X} 2$

Dari persamaan tersebut, angka 0.032 mempunyai arti bahwa semua variabel independen yang terdiri dari variabel tingkat pertumbuhan penjualan dan perputaran modal kerja dianggap bernilai nol, maka profitabilitas yang diwakili oleh ROA (Return ON Assets) mengalami kenaikan sebesar 0.032. Koefisien regresi tingkat pertumbuhan penjualan sebesar 0.069 (b1) mengandung arti bahwa apabila terjadi kenaikan sebesar satu kali pada pertumbuhan penjualan sedangkan variabel lainnya dianggap konstan, maka dalam hal ini profitabilitas akan meningkat 0.069 kali dengan tingkat signifikan $0.032>0,05$. Hal tersebut berarti dapat ditarik suatu kesimpulan bahwa variabel tingkat pertumbuhan penjualan berpengaruh terhadap tingkat profitabilitas perusahaan.

Besar koefisien regresi pada perputaran modal kerja sebesar -0.002 (b2) dengan signifikansi $0.085>0.05$. Hal tersebut berarti bahwa perputaran modal kerja perbengaruh negatif dan tidak signifikan terhadap profitabilitas. Adanya ketidaksignifikanan tersebut disebabkan oleh adanya peningkatan rasio perutaran modal kerja yang tidak diikuti oleh peningkatan pada profitabilitas dari perusahaan tersebut. Berikut adalah tabel Anova hasil output:

Tabel 5. Hasil Uji F

\begin{tabular}{lll}
\hline Model & F & Sig. \\
\hline Regression & 288.217 & .042
\end{tabular}

Berdasarkan Tabel 5, dapat diketahui bahwa nilai probabilitas yaitu sebesar 0.042 lebih kecil dari taraf signifikansi yaitu 0,05 persen. Hal tersebut menunjukkan bahwa tingkat pertumbuhan penjualan dan perputaran modal kerja berpengaruh signifikan terhadap profitabilitas yang diukur dengan rasio ROA. Sementara itu, hasil uji koefisien determinasi disajikan pada tabel berikut.

Tabel 6. Hasil Analisis Koefisien Determinasi Multiple $\left(\mathbf{R}^{2}\right)$

\begin{tabular}{lll}
\hline model & R Square & Adjusted R Square
\end{tabular}




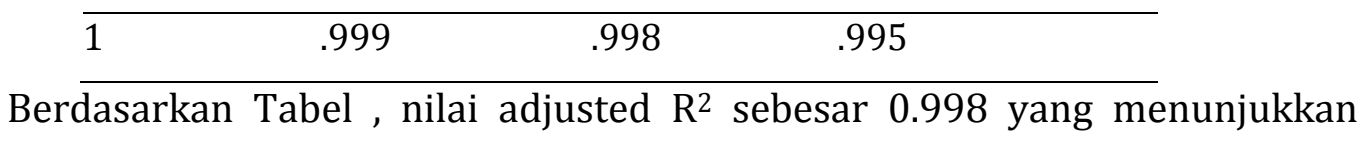
bahwa kontribusi pertumbuhan penjualan dan perputaran modal kerja sebesar $99.8 \%$ sedangkan $0.2 \%$ dipengaruhi oleh variabel lain di luar penelitian ini.

\section{HASIL DAN PEMBAHASAN}

Pertumbuhan penjualan secara parsial berpengaruh positif signifikan terhadap profitabilitas, hal tersebut berarti bahwa semakin tinggi tingkat pertumbuhan penjualan maka semakin tinggi pula profitabilitas perusahaan. Hasil dari perhitungan dan analisis tersebut, diperoleh bahwa H1 yang menyatakan pertumbuhan penjualan berpengaruh terhadap profitabilitas diterima dan H0 yang menyatakan bahwa pertumbuhan penjualan tidak berpengaruh terhadap profitabilitas ditolak. Hasil penelitian ini sesuai dengan penelitian Farhana, dkk (2016) yang mernyatakan bahwa terdapat pengaruh yang positif dan signifikan secara parsial pertumbuhan penjualan terhadap profitabilitas sebesar $50.2 \%$ pada PT. Madya Sejati di Singaraja tahun 2012-2014. Adanya pengaruh pertumbuhan penjualan terhadap profitabilitas perusahaan dikarenakan tingkat penjualan yang lebih besar dibandingkan dengan biaya usaha.

Tingkat pertumbuhan penjualan yang tinggi menandakan kemampuan perusahaan menghasilkan pendapatan yang tinggi dari penjualan produk perusahaan, sebaliknya jika pertumbuhan rendah menandakan kemampuan perusahaan menghasilkan pendapatan yang rendah dari periode sebelumnya. Dari laporan keuangan perusahaan PT. Tiga Pilar Sejahtera Food, Tbk tahun 2012-2015 menunjukkan bahwa perusahaan selama empat tahun tersebut mengalami penurunan pertumbuhan penjualan.Artinya bahwa pertumbuhan penjualan berpengaruh positif terhadap profitabilitas.Penurunan tersebut dapat disebabkan karena penjualan perusahaan yang tidak maksimal. Penjualan yang tidak maksimal dapat disebabkan karena kualitas produk yang ditawarkan ke konsumen menurun, sering kosongnya persediaan barang, penetapan harga jual yang tinggi, bertambahnya penjualan tetapi secara kredit, perubahan selera konsumen, munculnya pesaing baru, peningkatan piutang karena belum tertagih, sehingga 
menyebabkan penjualan rendah. Hal tersebut menunjukkan kurang optimalnya penggunaan sumber daya perusahaan untuk memaksimalkan laba dan berdampak pada penurunan ROA. Oleh karena itu, perusahaan harus mampu memaksimalkan penjualan. Karena ketika jumlah barang yang dijual semakin besar, maka biaya rata-rata persatuan produk akan semakin kecil sehingga ROA yang dihasilkan akan meningkat.

Modal kerja secara parsial tidak berpengaruh signifikan terhadap profitabilitas.Dari hasil tersebut dapat disimpulkan bahwa HO diterima.Artinya bahwa variabel perputaran modal kerja secara parsial (individu) tidak berpengaruh positif signifikan terhadap profitabilitas perusahaan.Hasil penelitian ini sesuai dengan penelitian yang dilakukan oleh Meidiyustiani (2016) yang menyatakan bahwa modal kerja (perputaran modal kerja) tidak memiliki pengaruh signifikan terhadap profitabilitas. Perusahaan membutuhkan modal kerja untuk mendukung kegiatan opersional pada saat terjadi peningkatan penjualan.Dengan tidak berpengaruhnya modal kerja terhadap profitabilitas perusahaan dapat disebabkan karena perputaran modal kerja yang tidak tinggi dan kurang efektif penggunaannya. Dari laporan keuangan PT. Tiga Pilar Sejahtera Food, Tbk menunjukkan peningkatan modal kerja yang tidak diiringi oleh peningkatan profitabilitas (ROA) perusahaan. Hal tersebut dapat disebabkan oleh modal kerja yang tidak diinvestasikan pada persediaan, kas yang ada di dalam perusahaan dalam jumlah yang banyak dan tidak dioptimalkan, jumlah piutang yang tidak tertagih besar yang mengakibatkan penjualan yang menurun dan berdampak pada sedikitnya jumlah laba kotor yang dihasilkan. Oleh karena itu, perusahaan harus mampu menggunakan modal kerja dengan seefektif mungkin untuk menghasilkan laba dengan demikian profitabilitas perusahaan dapat dioptimalkan.

\section{SIMPULAN}

Simpulan Berdasarkan hasil penelitian dari pembahasan sebelumnya, maka dapat disimpulkan bahwa Pertumbuhan penjulaan (growth) PT. Tiga pilar 
Sejahtera Foods,Tbk tahun 2012-2015 mengalami penurunan sehingga menunjukkan rasio yang kurang baik. Pertumbuhan penjulaan (growth) secara parsial (individu) berpengaruh positif signifikan terhadap profitabilitas perusahaan dengan tingkat signifikansi sebesar 0.032. Hasil tersebut sesuai dengan penelitian Farhana, dkk (2016) yang menyebutkan bahwa pertumbuhan penjualan berpengaruh positif secara parsial terhadap profitabilitas.

Perputaran modal kerja (working capital turnover) PT. Tiga Pilar Sejahtera Foods,Tbk tahun 2012-2015 mengalami peningkatan yang menunjukkan perputaran modal kerja yang lebih baik dari tahun sebelumnya. Perputaran modal kerja (working capital turnover)secara parsial (individu) tidak berpengaruh signifikan terhadap profitabilitas.hasil penelitian tersebut sesuai dengan penelitian yang dilakukan oleh Meidiyustiani (2016) yang menyebutkan bahwa perputaran modal kerja tidak memiliki pengaruh signifikan terhadap profitabilitas.

\section{PUSTAKA ACUAN}

Baidh, Murarilal, dkk. 2013. Effecte of Working Capital Management on Profitability of Company. Arusandhanika: Vol. V No. 1 \& 2. (6 Juni 2017).

Chen, Sylvia. 2015. Pengaruh Leverage, Likuiditas Dan Perputaran Modal Kerja Terhadap Profitabilitas. Jurnal Ilmu Dan Riset Manajemen : Volume 4 Nomor 10. (5 Agustus 2017).

Fahriyani, Iin. 2016. Pengaruh Ukuran Perusahaan, Investment Opportunity Set, Dan Profitabilitas Terhadap Kebijakan Deviden Dengan Debt To Equity Ratio Dan Kepemilikian Institusional Sebagai Moderating Variable. Jurnal Riset Akuntansi keuangan : Vol. 1 No. 1. Universitas Tidar Magelang. (6 Juni 2017).

Farhana, Cintya Dewi, Dkk. 2016. Pengaruh Perputaran Persediaan Dan Pertumbuhan Penjualan Terhadap Profitabilitas Pada PT. Ambarawa Madya SejatiDi Singaraja Tahun 2012-2014. E-Journal Bisma Universitas Pendidikan Ganesha Jurusan Manajemen : Vol. 4. (14 Juni 2017).

Fazeldadeh, Nina, dkk. 2016. Examining The Effect Of Independent Of The Board, Return On Investment, Profitability And Banking Relationship On Sales 
Growth Rate Of Listed Companies In The Tehran Stock Exchange. Journal of current research in science issn 2322-51009. (10 Juni 2017).

Harahap, Sofyan Syafri.2011. Analisis Kritis Atas Laporan Keuangan. Jakarta : Charisma Putra Utama Offset.

Kandpal, Vinayand and Prof P C Kavidayal. 2013. Implication Of Working Capital Management On The Profitability : A Case Of Ongc Ltd, India. Indian Journal Of Commerce \& Management Studies: Volume IV Issue. (31 Mei 2017)

Kieso, Donald E, dkk. 2007. Akuntansi intermediet. Terjemahan Emil Salim, S.E. Jakarta: Erlangga.

Meidiyustiani, Rinny. 2016. Pengaruh Modal Kerja, Pertumbuhan Penjualan dan Likuiditas Terhadap Profitabilitas Pada Perusahaan Manufaktur Sektor Industri Barang Konsumsi Yang Terdaftar Di Bursa Efek Indonesia Periode Tahun 2010-2014. Jurnal Akuntasi dan Keuangan : Vol. 5 No. 2. (14 Juni 2017).

Mulatsih. 2014. Analisis Tingkat Perputaran Persediaan, Tingkat Perputaran Piutang, Tingkat Perputaran Modal Kerja Dan Tingkat Perputaran Kas Terhadap Profitabilitas Pada Perusahaan Sektor Kimia Di Bursa Efek Indonesia 2010-2012. Jurnal Ekonomi Bisnis: Vol. 19 No.3. (14 Juni 2017).

Nawalani, Putrid Arinda dan Wiwik Lestari. 2015. Pengaruh Modal Kerja Terhadap Profitabilitas Pada Perusahaan Food And Beverages Di Bursa Efek Indonesia. Journal Of Business And Banking : Volume 5 Number 1. (8 Mei 2017).

Putra, AA Wela Yuliadan Ida Bagus Badjra. 2015. Pengaruh Leverage, Pertumbuhan Penjualan Dan Ukuran Perusahaan Terhadap Profitabilitas. E-Jurnal Manajemen Unud: Vol. 4 No. 7. (14 Juni 2017).

Qazi, Hassan Aftab, dkk. 2011. Impact of Working Capital on firm's profitability. African jornal of business management: Vol. 5(27). (6 Juni 2017).

-. $\quad$ 2006. Akuntansi Manajemen. Jakarta: Grasindo. 
Salehi, Mahdi And Sohila Torgeh. 2013. Recovery Period, Inventories, Sales Growth Cycles Amd Companies' Profitability: Empirical Evidence Of Iran. Academic Journal: Vol. 7 (21). (6 Juni 2017).

Setyawan,Supanji dan Endang P. 2016. Nilai Tambah dan profitabilitas Komoditas kelapa di kabuaten natuna. Jurnal RAK (Riset Akuntansi Keuangan) Vol 1 No 1 Tahun 2016 (6 Juni 2017)

Subramanyam, dan John J.Wild. 2012. Analisis Laporan Keuangan. Jakarta : Salemba Empat.

Trihendradi, Cornelius.2005. Step by step SPSS 13 analisis data statistic. Yogjakarta: Andi Offset. 